\title{
Assessment of Fruit Drop in Different Cultivars of Litchi
}

\author{
Narayan Lal ${ }^{1}$, Abhay Kumar2* E. S. Marboh ${ }^{3}$, Vishal Nath ${ }^{4}$ and S. D. Pandey \\ ICAR-Indian Institute of Soil Science, Bhopal, Madhya Pradesh (462 038), India \\ ICAR-National Research Centre on Litchi, Muzaffarpur, Bihar (842 002), India
}

\section{Corresponding Author}

Abhay Kumar

e-mail: abhayiari@gmail.com

\section{Article History}

Article ID: IJEP0429a

Received on $08^{\text {th }}$ June, 2021

Received in revised form on $20^{\text {th }}$ October, 2021

Accepted in final form on $24^{\text {th }}$ November, 2021

\begin{abstract}
Individual panicles produce hundreds of pistillate flowers but only a small proportion of these bear fruit and reach maturity. There are some stages of fruit drop during growth and development caused by different factors. An experimental trial was conducted in National Active Germplasm Site (NAGS) at ICAR-NRC on Litchi, Muzaffarpur, to assess the fruit drop due to different factors during 2014-2015. The result revealed that four factors viz., improper pollination and fertilization, embryo abortion, seed and fruit borer, and normal fruit abscission were associated with fruit drop in litchi and fruit drop varied from 23.53-77.54\% with a maximum in Shahi and lowest in Elaichi during the first week of flowering. Fruit drop increased to $92.65-97.86 \%$ during the third week of flowering because of improper pollination and fertilization, and it reached a maximum level of 98.51-99.70\% at the time of ripening stage with the lowest in Deshi. Embryo abortion was one primary cause of fruit drop during the $4^{\text {th }}$ week whereas infestation of seed and fruit borer was the major factor for fruit drop during the $5-7^{\text {th }}$ week. Such fruit drop can be controlled by managing the infestation of borer. Abscission due to ethylene production and heat stress during the maturity of fruit was yet another cause of fruit drop. This study will help to researcher to find out the time of infestation of seed and fruit borer which causes heavy fruit drop and it can be controlled with pest management option.
\end{abstract}

Keywords: Improper pollination and fertilization, embryo abortion, seed and fruit borer, abscission

\section{Introduction}

Litchi (Litchi chinensis Sonn.) is an important member of the Sapindaceae family (Lal et al., 2017) which has mycorrhizal association (Lal and Nath, 2020). Litchi is one of the most environmentally sensitive fruit trees restricted to a few countries in the world and to a few states in India. Recently, it has been reported that litchi is performing well in the southern part of India but major litchi producing states are Bihar, Uttarakhand, West Bengal, Punjab, Uttar Pradesh, Jharkhand and Tripura. Litchi starts flowering during February-March in Bihar conditions, and the intensity of flowering depends on temperature during floral bud differentiation, previous years fruiting and phenol content and age of plants (Lal et al., 2019a; Lal and Nath, 2020). A single panicle can produce hundreds of flowers ( $\mathrm{M} 1$ flowers, Female flowers and M2 flowers) and the success of fruit set depends on the pollen grain received from male parents (Lal et al., 2019b) and poor fruit retention due to fruit drop (Chang et al., 2015). The litchi fruit consists of about $55-85 \%$ pulp, 6-27\% seed and $10-28 \%$ peel which varies depending upon cultivar and climatic conditions. Litchi is a good source of vitamin C (Marboh et al., 2019). Lal et al. (2021a) indicated that although litchi is a highly cross-pollinated crop it does not mean that autogamy is not found in it. Cross-pollination by pollinators increased fruit set (Srivastava et al., 2017) and yields significantly in litchi by reducing fruit drop. An effective pollination period also affects the fruit drop (Lal et al., 2021b). Fruit drop, which is most common in litchi, continues from flowering to maturity and many factors are involved in it but fluctuation in temperature significantly affects the drop of the developing fruit. The failure in pollination and fertilization causes the first wave of fruit drop (Stern and Gazit, 2003). Besides this, low temperature, low humidity and rain also enhance fruit drop (Batten, 1986).

The excessive fruit drop is a major limiting factor in litchi production (Zhao and Li, 2020). Various attempts have been made to improve fruit set and retention as well quality of the fruit with exogenous application of plant growth regulators, nutrients and pesticides (Singh and Malik, 2005; Priyadarshi et al., 2018). Fruit drop to some extent can regulate the crop for next fruiting and commercial litchi production can also be manipulated by restriction of fruit load per panicle. The girth of panicle in litchi has been very strongly and positively correlated with fruit set/ retention, and low fruit drop has been found in thicker panicles (Lal et al., 2020).

Despite adequate flowering and initial fruit set, severe fruit drop contributes to a low fruit yield in litchi orchards and 
causes great economic losses in the litchi industries. Individual panicles produce hundreds of ovaries bearing flowers but only a small proportion of these bear fruit and reach maturity. Though a heavy fruit drop is experienced at different stages which starts from flowering and continues till harvesting, the factors involved in the various stages of fruit drop are still not identified. A knowledge of the stages of fruit drop and the associated factors would help the grower to identify the factors and apply effective measures to control fruit drop. Therefore, an experiment was carried out to assess the fruit drop in different cultivars of litchi.

\section{Materials and Methods}

The experiment was carried out in 2014 and 2015 on nine different early maturing cultivars (Late large red, Trikolia, Elaichi, Dehrarose, Deshi, Dehradoon, Rose Scented, Shahi and Ajhauli) planted in a square system, each having a uniform age of 7 years in the National Active Germplasm Site (NAGS), at an ICAR-National Research Centre on Litchi, Muzaffarpur, Bihar. All the cultivars were maintained under the same culture practices which were uniform in size and twenty panicles were tagged in each cultivar in four directions (North, South, East and West) and from each direction five panicles were selected. The number of female flowers were counted from the tagged panicle and the data on fruit drop (\%) was recorded at a weekly interval from the first week of pollination to harvesting ( $9^{\text {th }}$ week). The area beneath the canopy of the tree was kept clean throughout the observation period. From $4^{\text {th }}$ week onwards, after fruit set, all the dropped fruits were collected at a weekly interval from the individual cultivars; these fallen fruits collected beneath the canopy area of each genotype were cut and examined. The experimental fruits were divided into three categories: 1 . fruits in which embryo was aborted; 2 . normal fruits in which seed as well as fruit was free from any damages/abnormalities (healthy); and 3. seed borer affected fruit where seed was having tunnel on solid endosperm probably made by larvae of seed and fruit borer.

\section{Results and Discussion}

Flower and fruit drop are common problems in most of the fruit crops including litchi but it causes economic losses when it goes beyond the threshold level. The maximum fruit drop during first week of pollination was recorded in Shahi (77.54\%), whereas the lowest was in Ellaichi (23.53\%). The lowest fruit drop in Ellaichi was due to the colour of its thalamus (pink colour) which attracted more number of insects, and this encouraged more initial fruit set. The fruit drop was varied from $88.56-97.86 \%$ at fortnight interval, 92.65-97.86\% up to the third week and 98.51-99.70\% during the ripening stage with the lowest in Deshi (Table 1). Flower and fruit drop began during blooming and continued up to maturity. Four main factors-improper pollination and fertilization, embryo abortion, seed and fruit borer, and normal fruit abscission were identified to be responsible for fruit drop in litchi. Lal et al. (2021a) observed fruit drop in the range of $98.77 \%$ in Dehradoon to $96.84 \%$ in Rose Scented. The differences in the level of fruit drop might be due to a variation in the age of plants. Young plants exhibited a heavier fruit drop than older ones.

Dabral and Misra (2007) also recorded the maximum fruit

Table 1: Percentage of successive fruit drop at weekly interval in litchi

\begin{tabular}{lccccccccc}
\hline Cultivar & $1^{\text {st }}$ week & $2^{\text {nd }}$ week & $3^{\text {rd }}$ week & $4^{\text {th }}$ week & $5^{\text {th }}$ week & $6^{\text {th }}$ week & $7^{\text {th }}$ week & $8^{\text {th }}$ week & $9^{\text {th }}$ week \\
\hline Late large red & 70.86 & 85.58 & 92.94 & 93.25 & 96.01 & 96.93 & 97.55 & 98.77 & 98.77 \\
Trikolia & 56.86 & 90.34 & 94.08 & 95.18 & 96.26 & 97.82 & 97.82 & 99.07 & 99.07 \\
Elaichi & 23.53 & 89.71 & 92.65 & 93.24 & 97.65 & 97.65 & 98.24 & 98.82 & 98.82 \\
Dehrarose & 71.84 & 95.86 & 97.93 & 98.05 & 98.85 & 99.08 & 99.31 & 99.31 & 99.31 \\
Deshi & 74.26 & 89.44 & 93.23 & 94.72 & 96.37 & 97.36 & 97.52 & 98.51 & 98.51 \\
Dehradoon & 68.69 & 92.10 & 93.92 & 94.69 & 94.83 & 96.35 & 96.66 & 99.70 & 99.70 \\
Rose Scented & 56.64 & 91.94 & 96.21 & 97.40 & 99.05 & 99.05 & 99.05 & 99.05 & 99.05 \\
Shahi & 77.54 & 97.86 & 97.86 & 98.14 & 98.93 & 98.93 & 98.93 & 99.47 & 99.47 \\
Ajhauli & 39.06 & 88.56 & 94.78 & 95.65 & 98.51 & 98.69 & 99.07 & 99.07 & 99.07 \\
SEm \pm & 0.623 & 0.487 & 0.367 & 0.351 & 0.376 & 0.389 & 0.320 & 0.246 & 0.246 \\
CD $(p=0.05)$ & 1.882 & 1.471 & 1.109 & 1.061 & 1.136 & 1.177 & 0.967 & NS & NS \\
\hline
\end{tabular}

set in Rose Scented (23.69\%) and the minimum was found in Dehradun (17.92\%). It seems that there is a wide variation in the findings of fruit drop in litchi. The variation in fruit drop may be due to different growing condition, local weather conditions, age of plants and year of study, but in the case of the present study, the comparatively younger plants had more fruit drop; workers, on the other hand, reported a comparatively low fruit drop in aged plants. Hence, the role of the age of plants regarding flowering in litchi cannot be overlooked (Lal and Nath, 2020).

Litchi produced three types of flowers [Male flower (M1), hermaphrodite functionally female flower (F) and 
hermaphrodite Male flower (M2)] in which heterostyly as well as self-incompatibility has been recorded in Female and $\mathrm{M} 2$ flowers and both these conditions promoted cross pollination. The process of pollination and fertilization induces production of growth regulators in the ovary, the ovaries enlarge and fruit development is initiated but a lack of pollination resulted in heavy flowers and fruit drops. The lack of complete pollination or fertilization was the main reason of flowers and fruit drop up to the $3^{\text {rd }}$ week of pollination. About $90-95 \%$ fruit drop occurred up to the $3^{\text {rd }}$ week which seemed to be natural drop and difficult to control. The initial drop comprised mostly of un-pollinated flowers as the lifespan of individual litchi flowers were very short and many flowers were apparently not pollinated during their receptive period. Chang et al. (2015) also reported massive fruit drop in litchi. Mehdi et al. (2007) also found that improper pollination and fertilization caused heavy fruit drop, small proportion (0.1-0.25\%) set fruit and reached maturity.
Shrivelling and blackening of the ovule were reported in litchi fruits dropped off during the $4^{\text {th }}$ week. During this week, embryo sacs remained in the liquid stage. The maximum fruit drop due to abortion was recorded in Deshi followed by Late large red (Figure 1) and fruit drop due to abortion of embryo decreased drastically in Deshi during the $5^{\text {th }}$ week (Figure 2) after about 94-99\% fruit dropped off. Embryo abortions have been found during the development of fruits. Pollen grain has an important role in the successful development of embryos; Lal et al. (2019c) reported that the success of fruit set was influenced by sources of pollen grains. It has been observed that high temperature and drought increased embryo abortion during the $4^{\text {th }}$ week (15 April). Fruit drop at Pea stage is due to embryo abortion and this abortion hinders normal fruit development and causes abscission layer at the early stages of fruit development (Mehdi et al., 2007).

An interesting result was obtained regarding infestation of

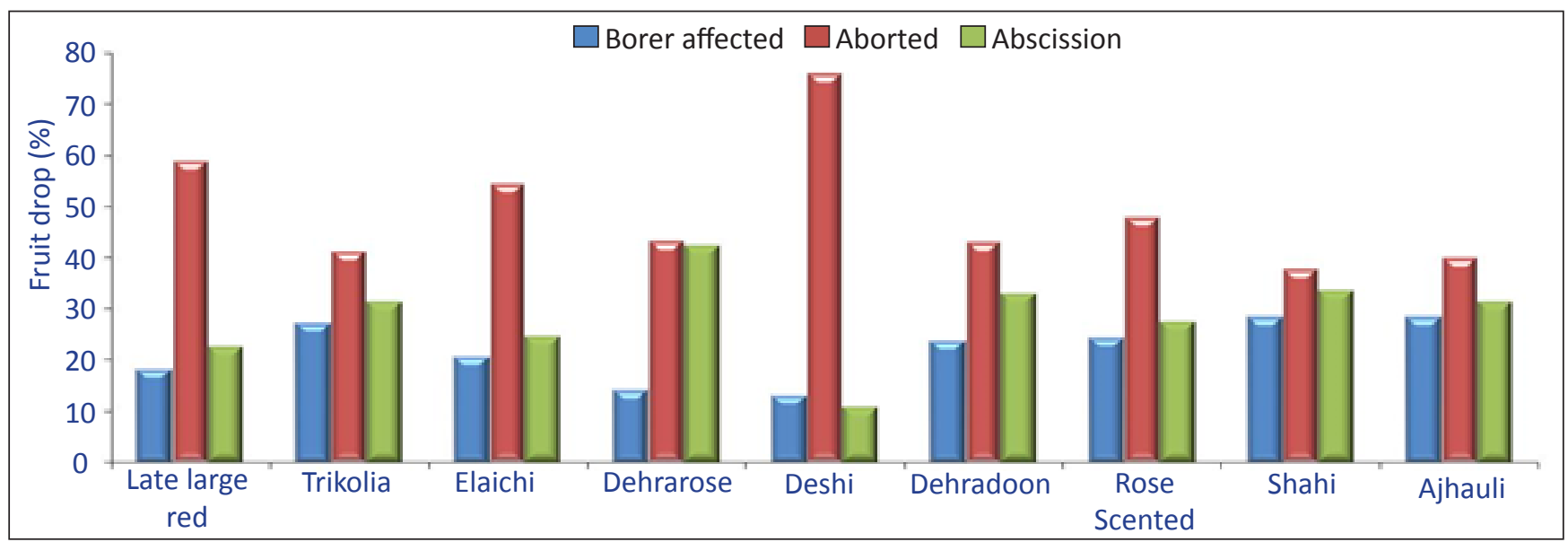

Figure 1: Fruit drop durring $4^{\text {th }}$ week in different cultivars

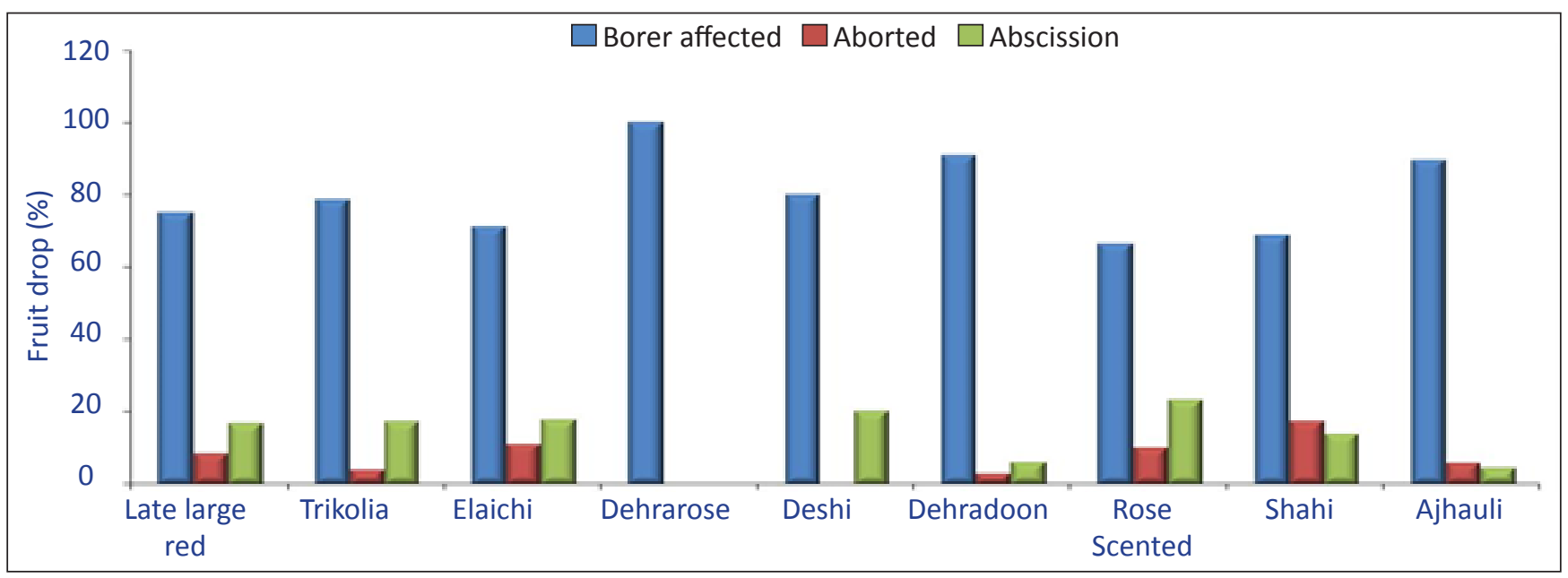

Figure 2: Fruit drop durring $5^{\text {th }}$ week in different cultivars

seed and fruit borer (Conopomorpha spp.) which suddenly increased during the $5^{\text {th }}$ week and caused heavy fruit drop, and fruit drop due to abortion of embryo and abscission greatly reduced (Figure 2, 3 and 4). The infestation of borer started from the $5^{\text {th }}$ week and continued till maturity of the fruit. However, borer infestation declined during the $8^{\text {th }}$ week. Seed 


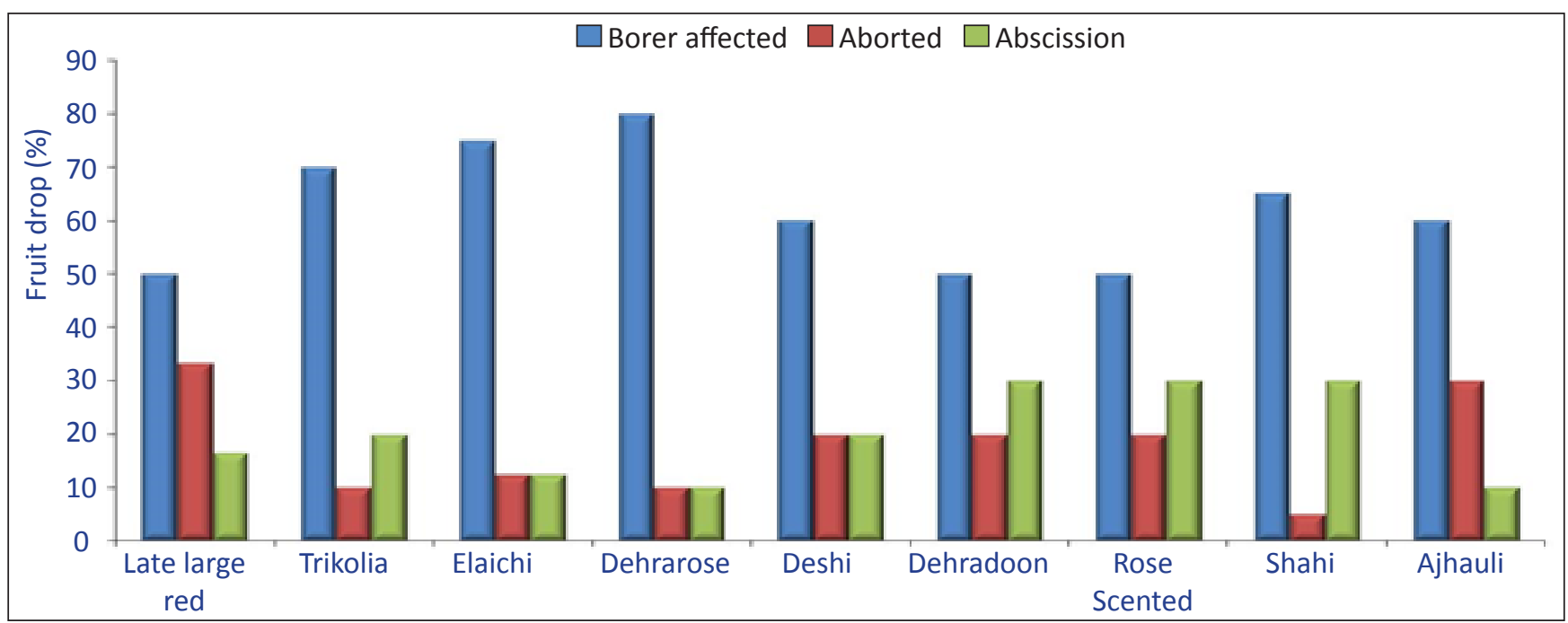

Figure 3: Fruit drop durring $6^{\text {th }}$ week in different cultivars

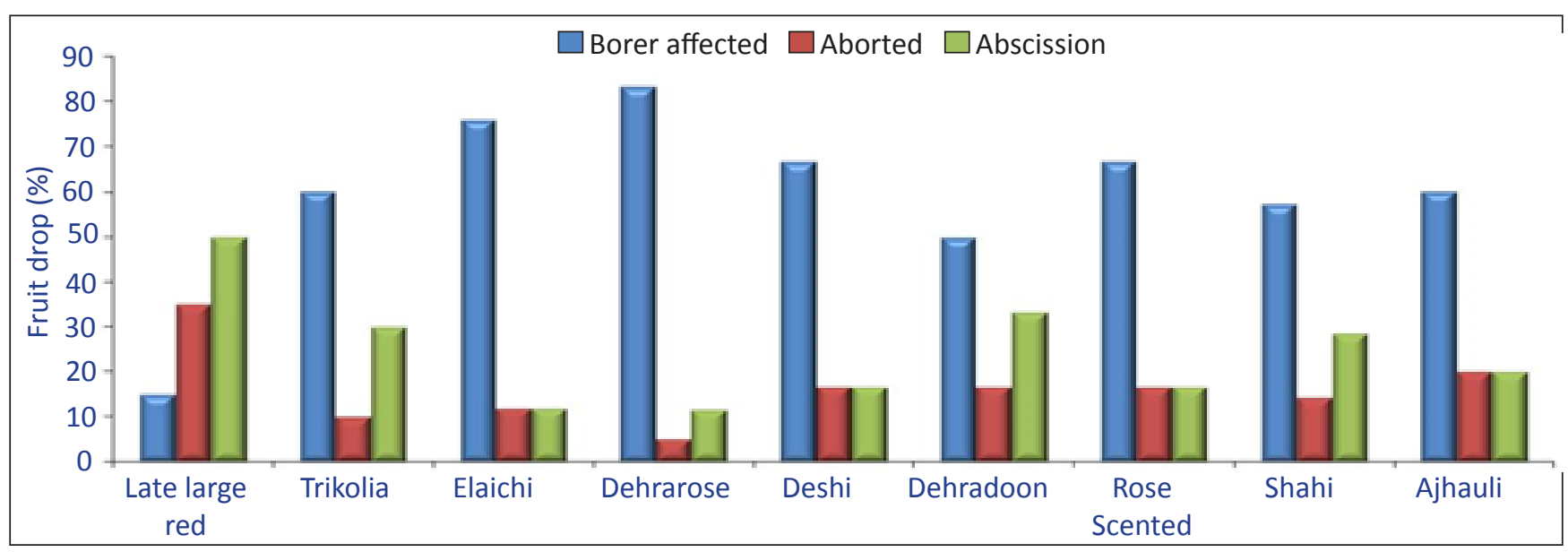

Figure 4: Fruit drop durring $7^{\text {th }}$ week in different cultivars

and fruit borer is a major problem in litchi production which causes heavy losses during maturity because of infection. Insects started to bore seeds during growth and development of fruits which fed on the seeds and caused heavy fruit drop. Fruit drop at this stage can be controlled by managing the infestation of borer. The mango midge caused drop up to $70 \%$ and mango hopper was also a major pest, causing 25-60\% fruit loss (Mehdi et al., 2007). Mango mealy bug is a serious pest causing great losses to immature fruits in India and Pakistan (Mohyuddin and Mahmood, 1993).

The mechanism by which insect damage induced fruit abscission was probably as varied as the damage they incur. The generation of ethylene was involved either through wound effects or directly in infected tissues (Martinez et al., 2001).

The dropping of normal or fresh fruit due to abscission started during the $8^{\text {th }}$ week (Figure 5). At the time of maturity, the drop of normal fruit was highly increased and embryo abortion was totally reduced. It seems that May drop due to heavy temperature and mechanical shock led to abscission layer formation and, at this time, seeds which became fully mature (brown colour) might have contributed abscisic acid (ABA) which was diverted to the pedicel. Abscission zone was formed at the attachment point of fruit pedicels due to high temperature and ethylene production. Whiley and Schaffer (1997) reported that ethylene biosynthesis caused fruit drop in mango. Fruit drop is mainly due to an imbalance between the level of IAA and ethylene within fruit tissues and abscission zone (Yuan and Carbaugh, 2007; Yuan and Li, 2008; Li and Yuan, 2008; Zhu et al., 2010).

According to Racsk et al. (2007), in one-seeded fruits like stone fruits, fruit drop in June month increased when the growth of embryos was intense. At this stage, the embryo consumes most of the endosperm which is coincident with a lag phase of fruit growth often associated with fruit drop. When the embryo completes its growth, the secondary endosperm appears and starts to produce auxin that is required for inhibiting abscission. Yuan and Huang (1988) reported that the multi-waves of fruit abscission in litchi was parallel to the upsurges of abscisic acid (ABA) in the seed. 


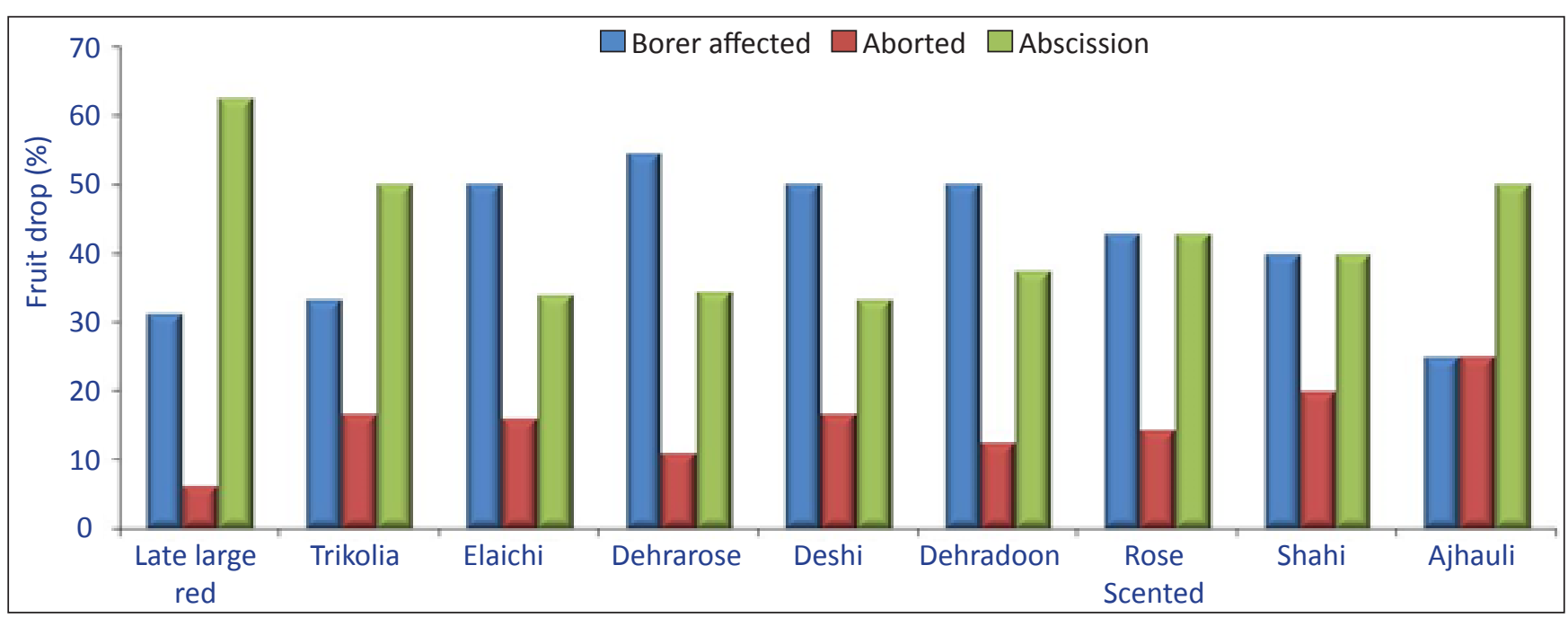

Figure 5: Fruit drop durring $8^{\text {th }}$ week in different cultivars

\section{Conclusion}

The improper pollination and fertilization triggers fruit drop up to the $3^{\text {rd }}$ week, and embryo abortion promotes fruit drop during the $4^{\text {th }}$ week. The attack of seed \& fruit borer starts right from the $5^{\text {th }}$ week and continues until the $8^{\text {th }}$ week causing heavy fruit drop of the developing litchi fruit. Such fruit drop can be controlled by managing the infestation of borer. Abscission of the developing fruit starts during the $8^{\text {th }}$ week, at maturity, causing dropping of normal fruit.

\section{Acknowledgements}

Authors are thankful to ICAR-NRC on litchi for providing all the facilities for undertaking the study.

\section{References}

Batten, D.J., 1986. Towards an understanding of reproductive failure in lychee (Litchichinensis Sonn.). Acta Horticulturae 175, 79-83.

Dabral, M., Misra, K.K., 2007. Studies on flowering and fruiting in some litchi cultivars. Indian Journal of Horticulture 64(2), 207-210.

Chang, J.Y., Chang, Y.A., Tang, L., Chang, J.W., 2015. Characterization of generative development in early maturing litchi 'Early Big', a novel cultivar in Taiwan. Fruits 70, 289-296.

Lal, N., Gupta, A.K., Kushwah, N.S., Nath, V., 2017. Sapindaceous Fruits. In: Peter, K.V. (Ed.), Horticultural Crops of High Nutritive Values. Brillion Publishing, 339-370.

Lal, N., Gupta, A.K., Marboh, E.S., Kumar, A., Nath, V., $2019 b$. Effect of pollen grain sources on success of hybrids in 'Bedana' Litchi. International Journal of Bioresource and Stress Management 10(3), 241-245.

Lal, N., Gupta, A.K., Marboh, E.S., Kumar, A., Nath, V., 2019c. Effect of pollen grain sources on fruit set and retention in 'Shahi' litchi. Multilogic in Science 9 (29), 152-156.

Lal, N., Gupta, A.K., Marboh, E.S., Kumar, A., Nath, V., 2021 a.
Effect of mode of pollination on fruit set and fruit characteristics in litchi. Erwerbs-Obstbau 63, 227-232.

Lal, N., Kumar, A., Nath, V., 2020. Quantitative analysis of relationships between panicle size and fruit traits in litchi (Litchi Chinensis Sonn.). International Journal of Bio-resource and Stress Management 11(4), 381-386.

Lal, N., Nath, V., 2020. Effect of plant age and stress on flowering in litchi (Litchi chinensis). Current Horticulture 8(1), 24-27.

Lal, N., Sahu, N., Marboh, E.S., Gupta, A.K., Kumar, A., Nath, V., 2021b. Effect of pollen grain and pollination period on fruit set in litchi (Litchi chinensis Sonn.). National Academy of Science \& Letters 44(5), 461-464.

Lal, N., Singh, A., Gupta, A.K., Marboh, E.S., Kumar, A., Nath, V., 2019a. Precocious flowering and dwarf NRCL-29-A new genetic stock of litchi (Litchi Chinensis Sonn.). Chemical Science Reviews \& Letters 8 (32), 206-210.

Li, J., Yuan, R., 2008. NAA and ethylene regulate expression of genes related to ethylene biosynthesis, perception and cell wall degradation during fruit abscission and degradation in delicious apple. The Journal of Plant Growth Regulation 27(2), 283-295.

Marboh, E.S., Gupta, A.K., Singh, M., Lal, N., Nath, V., 2019. Litchi. In: Peter, K.V. (Ed.), Origin and Biological Diversity of Horticultural Crops. Brillion Publishing, 107-137.

Martinez, G.P., Gomez, R.L., Gomez-Lim, M.A., 2001. Identification of an ETR 1-homologue from mango fruit expressing during fruit ripening and wounding. Plant Physiology 158, 101-108.

Mehdi, M., Muhammad, S.M., Abdul, J., 2007. Causes and potential remedies of mango (Mangifera indica L.) fruit drop in Pakistan. In: International Symposium on Prospects of Horticultural Industry in Pakistan, 6.

Mohyuddin, A.I., Mahmood, R., 1993. Integrated control of mango pests in Pakistan. Acta Horticulturae 341, 467-483. 
Priyadarshi, V., Hota, D., Karna, A.K., 2018. Effect of growth regulators and micronutrients spray on chemical parameters of litchi (Litchi chinensis Sonn.) cv. Calcuttia. International Journal of Economic Plants 5(3), 99-103.

Racsk, J., Leite, G.B., Petri, J.L., Zhongfu, S., Wang, Y., Szab, Z., Soltesz, M., Nyeki, J., 2007. Fruit drop: The role of inner agents and environmental factors in the drop of flowers and fruits. International Journal of Horticultural Science 13(3), 13-23.

Stern, R.A., Gazit, S., 2003. The reproductive biology of the lychee. Horticultural Reviews 28, 393-453.

Singh, Z., Malik, A.U., Davenport, T.L., 2005. Fruit drop in mango. Horticultural Review 31, 113-156.

Srivastava, K., Sharma, D., Pandey, S.D., Anal, A.K.D., Nath, V., 2017. Dynamics of climate and pollinator species influencing litchi (Litchi chinensis) in India. Indian Journal of Agricultural Sciences 87(2), 266-269.

Whiley, A.W., Schaffer, B., 1997. Stress Physiology. In: Litz, R.E. (Ed.), The Mango-Botany, Production and Uses. CAB International, 147-173.
Yuan, R., Carbaugh, D., 2007. Effects of NAA, AVG, and 1-MCRP on ethylene biosynthesis, preharvest fruit drop, fruit maturity and quality of 'Golden Supreme' and 'Golden delicious' apple. Horticultural Science 42(1), 101-105.

Yuan, R., Huang, H., 1988. Litchi fruit abscission: its patterns, effect of shading and relation to endogenous abscisic acid. Scientia Horticulturae 36, 281-292.

Yuan, R., Li, J., 2008. Effect of sprayable 1-MCP, AVG, and NAA on ethylene biosynthesis, preharvest fruit drop, fruit maturity and quality of delicious apple. Horticultural Science 43(5), 1454-1460.

Zhu, H., Yuan, R., Greene, D.W., Beers, E.P., 2010. Effects of 1-methylcyclopropene and naphthalene acetic acid on fruit set and expression of genes related to ethylene biosynthesis and perception and cell wall degradation in apple. Journal of American Society for Horticultural Science 135(5), 402-409. 